\title{
Geopolitics of border securitization: sovereignty, nationalism and solidarity in asylum reception in Finland
}

Author:

Prokkola Eeva-Kaisa

Geography Research Unit

University of Oulu

eeva-kaisa.prokkola@oulu.fi

$+3585568241$

\begin{abstract}
The paper examines the security interventions at the northern Finnish-Swedish border crossing point in the town of Tornio, the particular focus being on the 2015 migration influx in which Finland received a tenfold increase in asylum applications compared with the previous years (32 476 asylum applicants). The securitization of the Finnish-Swedish border and the organization of asylum reception practices, in which nongovernmental organizations also played an important role, created tension between the Finnish and Swedish authorities, borderlanders, and within wider Finnish society. An empirical study of various materials (documents, interviews, social media debates and media reports) is used to examine the coexistence and intertwining of different border securitization practices and discourses. The analysis is structured around three storylines that disclose border securitization as multiple and continues to problematize the assumption that the states, as entities holding sovereign authority, fully determine the matter of border securitization. Firstly, the state intervention examined here occurred through and fully depended on collaboration with local authorities and nongovernmental actors. Secondly, nationalistic groups mobilized demonstrations against immigration and started independent street patrols in the name of security, throwing into
\end{abstract}


question the effectiveness and authority of the state government in matters of border securitization. Thirdly, the discourses of the securitized Finnish-Swedish border reflect the wider solidarity crisis between EU countries and in their sharing of sovereignty. The study complicates the understanding of border securitization as a straightforward state effort and provides a picture of a hybrid border securitization environment. 


\section{Introduction}

In August 2015, hundreds of migrants and asylum-seekers started to arrive daily at the northern Finnish-Swedish border crossing point in the town of Tornio, having travelled all the way through Europe and Sweden. The situation was considered exceptional in Finland and the notion of a unique kind of threat started to dominate the public debate. Within a few weeks, the Finnish government relocated hundreds of policemen, border guards, security authorities and servicemen to Tornio to control the border crossing and to register the asylum-seekers. The open EU-internal Finnish-Swedish border was securitized; border-related issues and border crossings came to be approached from the perspective of security as opposed to the prioritizing of freedom of mobility and human rights (Huynsman 2000; Tesfahuney 1998; Ackleson 2005; Hyndman 2010).

This paper examines the rather problematic and contradictory security interventions at the FinnishSwedish border crossing point, and analyzes border securitization efforts from the perspective of territorial sovereignty. International borders, the physical border walls, are often considered the most visible manifestations of state territorial sovereignty, its geographical demarcation. The FinnishSwedish border, which is often lauded as the most peaceful border in the world by the local borderlanders, provides an interesting case from the perspective of border securitization - in the "exceptional circumstances" that resulted from "continuous significant secondary movements" (see EC 2018) - for a number of reasons. Firstly, the Nordic countries made an agreement to relinquish passport checks in 1957, which means that border crossing has been unrestricted for six decades. Secondly, in comparison to the other Nordic countries which have considerable immigrant populations, Finland has been a country of immigration only since the twenty-first century and only approximately one percent of the population has a refugee status or background (FRC 2017). Thirdly, the protection of state borders has been a matter of crucial importance in the construction of the Finnish national identity (Paasi 1996), and the shared conception of Finnishness as something based 
on racial and cultural homogeneity has made the country rather exclusive (Häkli 2005). Border securitization in Finland is therefore closely linked with the national geo-history and identity securitization.

This study aims to contribute to the discussion of borders, securitization and territorial sovereignty by scrutinizing border securitization as multiple (cf. Mol 2002; Andersen and Sandberg 2012), that is, border securitization is not conceived of as a straightforward state effort but as a set of performed practices enacted by state authorities and other governmental and non-governmental actors, often in partnership with each other. The border securitization multiple approach aims at revealing to what extent there exist competing and contradictory narratives about border securitization, paying attention to the intersections between formal border security institutions, the state and the EU, and the more situational and mundane practices of drawing boundaries, often termed 'borderwork' (Rumford 2008). By this means, it is possible to gain a deeper understanding of the complexity of border securitization efforts, and how the practices carried out in the name of security, such as tightened border controls and demonstrations against open borders, may not simply reinvent state sovereignty but question it by offering a different version of territorial sovereignty. The complexity of border securitization in the context of 2015 migration influx provides a fertile ground for scrutinizing how sovereignty is enacted in a specific hybridized manner (Fregonese 2012a). It is important to note, however, that although state border walls are seen as markers of sovereignty, territorial sovereignty by definition (Philpott 1995; Coleman 2009, 255) does not presume security approach to borders and border crossing. Border securitization is always a highly political and politicized act (Prokkola 2013a).

The empirical study focuses on the Finnish-Swedish border crossing point in Tornio, which is a small border town in northern Finland. The Tornio border crossing point formed the key route for asylumseekers travelling to Finland and a specific site of state intervention and nationalistic mobilization as well as a site for negotiating the Finnish-Swedish neighborhood relations. By focusing on this 
particular border location, it is possible to examine how different governmental and nongovernmental actors produce border security and insecurity through the practices of care, control and deterrence (cf. Pascucci, Häkli, and Kallio 2019) and how the authority to carry out actions in the name of territorial security becomes reified, co-constituted and contested in the process. In the EU internal border areas like the Finnish-Swedish border area, the complex contests over border securitization are not a merely state-internal question but becomes a site for testing, revising and even abandoning the political and economic treaties, agreements and solidarity of the Union itself.

The paper first discusses border securitization from the perspective of territorial sovereignty and introduces the methodological approach of the study. Next, the findings are analyzed and discussed in three thematically organized sections on the following topics: the securitization and militarization of the Finnish-Swedish border crossing point in Tornio; the mobilization of extreme nationalists; and the question of solidarity among the neighboring EU member states. The securitization of the FinnishSwedish border is interpreted against the specific economic, cultural and geopolitical environment of Finland.

\section{Geopolitics of border securitization and sovereignty}

Border fences and strict border controls are often seen to form the most visible element of state sovereignty, protecting the population of the territory from external invasions. However, after the long prevalence of the foreign policy perspective in the studies of security and geopolitics that entrenched an understanding of border security as the exercise of state sovereign power, scholars are more and more recognizing the importance of other possible spheres and spaces of security/insecurity (Coleman 2009). It has been shown how besides the foreign policy "security writing" (Campbel 1992), the mobilization of the discourses of danger and corresponding practices of border security 
emerge from the activities of non-institutional actors (Huynsman 2000, 758; Doty 2007), sometimes conflicting and sometimes in line with the formal governmental security efforts.

The widening of the perspective usually means that border security is not understood to refer only to state territorial security and defense in their traditional meaning but is seen to encompass wider societal questions as well as economic and infrastructural security issues (Bigo 2001; Prokkola 2013a). Moreover, many scholars have turned their analytical lens from the concept of security, as some kind of an ontological condition of a state, towards securitization. The idea of securitization is based on the work of the Copenhagen School, which emphasizes the social construction of the object of security efforts, the threat (Buzan, Wæver, and de Wilde 1998; Strizel 2007). In this reading, the utterances of "leaking borders" and "migration flows" as security problem, often circulated in political and media debates, are not understood as factual descriptions of the world. Instead, they are understood to mobilize particular understandings about the world, dehumanize migrants, and help in justifying intensified border controls and the building of new border walls (Prokkola 2013b). The securitization of borders has led to the construction of new border walls around the world, clearly pointing out how border securitization is not merely a question of linguistic construction but materializes in and through the intertwined practices of security and insecurity, and the attendant production, communication, reception and alteration of the ideas of threat and danger (Balzacq 2005). Some scholars have argued, interestingly, that the increased interest of states in establishing border walls does not signify the uncontested authority of the states but the waning of their sovereign power (Brown 2010; cf. Brown 2017). From this perspective, border fences are a last-ditch attempt to sustain the appearance that states still maintain control over their territory. Other scholars disagree with the idea that the construction of border fences signifies waning state power. Jones and Johnson (2017, 192) strongly argue that border militarization should rather be understood as "a spatial re-articulation of sovereign power, not as the evidence of its demise" and as "the redirection of sovereignty's focus on securing the borderline against the highly mobile objects of security risks posed by migrants and 
protecting economic privilege." They also note that border walls provide only one manifestation of the heightened security demands and techniques through which states strive to regulate and control mobilities within and across territories (see also Jones 2012). In this new phase of border securitization the danger that the border wall aims to prevent is not the military attack by another sovereign power but migrant groups, "risky others," and a particular type of transnational mobility. Hence, the contest over the legitimate determination of the friend-enemy distinction, something that is often considered the marker of sovereignty (Schmitt 1997/1922), has widened from the realm of foreign policy and international relations (Brown 2010, 20) to the question of national identity securitization and ethnicity policies.

As scholars in political geography and IR have shown, one means to overcome the question whether border security efforts and militarization should be interpreted as a manifestation of the weakening of state power or not is to shift the focus onto the concept of sovereignty itself. Referring to E.H. Hinsley's (1966) classical work, Coleman $(2009,255)$ provides a definition of sovereignty as "the exclusive, independent, and transcendent right of an entity, person, or political body to exercise ultimate legal-political authority over an invisible geographical area and its attendant population, conceived as an amalgamated body politic." Yet, this definition in itself indicates how absolute territorial sovereignty, the setting of limits to all social practice, is neither desirable nor possible. Accordingly, there is an ongoing interdisciplinary debate over the definition of sovereignty, what is sovereign, where and how (see Coleman 2009; McConnell 2013).

Accordingly, many political geographers have problematized the assumption of the territorial, bounded nature of the sovereignty (Kuus and Agnew 2008, 96; Mountz 2013). The complex spatialities of border enforcement provide a fitting example of how sovereign power can be enforced at multiple sites and scales, both within a territory and extraterritorially (Casas-Cortes, Cobarrubias, and Pickles 2016; Jones and Johnson 2017; Ackleson 2005). Jones and Johnson (2017), among others, underline the importance of recognizing the sites of new sovereignty practices and of identifying the 
actors enacting the sovereign state. Beside that, it is useful to pay attention to the multiplicity of borders and to possible challenging of state rule in the domain of border control and security. As Doty (2007) shows, border securitization can become an arena for contesting the rule of state authority from the ground up, and may heighten tensions between state agencies, nationalistic groups, international organizations, and within society as a whole.

While many studies discussing border securitization focus on the state-migrant relationship something that often reinforces the traditional idea that the state, as a single entity, holds sovereign power over its territory - this study aims to complicate an understanding of securitization as straightforward state effort. Rather than simply affixing sovereignty to state territory and normative legal-political authority to decide an exception, in this paper the complexity of border securitization are interpreted in terms of what Fregonese calls 'hybrid sovereignty' (Fregonese 2012a, 2012b). Following this understanding, the analysis should recognize how "specific hybridizations between state and non-state sovereignty" take place and how the control of space is claimed by non-state actors who are "not the state but resemble it, collaborate with it, or overpower it" (Fregonese 2012a, 294). The conception of hybrid sovereignty highlights how geographies of power are not only shaped by the state but by non-state actors as well. Thus, it enables us to pay attention to possible different versions of sovereignty in time and space, like how regional and urban spaces form sites of sovereignty co-constitution, how border vigilantes may assert authority over local security (Doty 2007), and how individual EU member states' border security practices are regulated by supranational agreements. Finally, simultaneous enactment and justification of multiple versions of border security often creates tensions and negations between different actors, as well as undesired security responses; for instance, the heated dialogue surrounding border securitization increased the polarization of Finnish society as a whole (Puustinen et al. 2017; Prokkola 2019). 


\section{The border securitization multiple approach}

In this study, border securitization at the Finnish-Swedish border and the Tornio border crossing point in particular, has been approached by analyzing multiple, situational and shifting practices and discourses claiming insecurity and security. The border securitization multiple approach is drawn from Mol's (2002) theorization of "body multiple" and Andersen's and Sandberg's idea of "the border multiple" $(2012,17)$ which suggests that borders should not be seen as actual entities but "as performed or enacted effects of the multiple practices through which they are made." Mol's work on practical philosophy takes Foucault's work on medical institutions as the point of reference, focusing on localized production of multiple versions of 'reality' rather than on the knowledge production and embedded power relations which Foucault underlines. By examining the series of different practices of a particular disease in a single Dutch hospital, Mol shows that what is normally understood to form a single object may actually appear to be more than one. She (2002, viii) underlines that even if in practice the body is more than one, it is not "fragmented into being many." As Andersen, Kramsch and Sandberg $(2015,463)$ show, the idea of ontological multiplicity (Mol 2002, 1999) directs our attention to "reality as always and everywhere politically contestable", that is, to the possibility of enacting different versions of border security. Inspired by Mol, Andersen and Sandberg $(2012,7)$ emphasize that researchers should think creatively about what borders are, and focus especially on "showing for whom they are and how those for whom they are, enact and perform them." This kind of approach enables us to pay attention to border securitization efforts as particular sites for making claims about territorial sovereignty, and is in line with the conception of sovereignty as hybrid.

Instead of studying whether the claims about the border situation at the Tornio crossing point are accurate, this paper investigates how borders become conceptualized and enacted in practice by various governmental and non-governmental actors, and how each actor and expert produces a version of border security and thus its "treatment". The actors (or experts, by using Moll's 
terminology) look at the world, and thus borders, from different standpoints (Mol 1999, 76). This kind of understanding provides a fruitful starting point for studying securitization in a particular border location; it encourages us to pay attention to the activities, practices and standpoints of multiple actors in the process of securitizing the Finnish-Swedish border instead of taking the state's security practices as the sole point of reference (cf. Andersen and Sandberg 2012). The production of the discourses of threat and danger is not solely in the hands of state elites, and it is therefore fruitful to examine other, more contextual, local and mundane interpretations of borders and security.

The study is based on different sets of materials that provide insights into many different versions of border securitization and its legitimization. The material includes nineteen (19) open-ended interviews conducted among local authorities and non-state actors who participated in the 2015 asylum reception in the town of Tornio. The interview questions focused more on the activities and experiences of the participants than on their conceptions and attitudes, something that enables us to gain an understanding of how border security practices and control were organized and conceptualized locally. However, the interview narratives though which local actors' practices, experiences and participation in the asylum reception were studied and documented suggest that at the local level border security often gains meaning in relation to local people's own experiences as well as wider societal discourses and knowledge. The empirical material also includes 365 questionnaire responses from Tornio inhabitants (a random sample). The tape-recorded and transcribed interviews and the questionnaire responses have been stored and coded according to the guidelines of the Finnish Advisory Board on Research Integrity. The interviews and the open responses of the questionnaire provide an understanding of local people's activities, experiences and perceptions regarding migration and border securitization. In addition, the empirical material includes reports from the Finnish ministries and the government, media articles and social media discussions. A systematic analysis of migration- and border-related discussion was conducted in the open discussion forum Suomi24 TornioHaparanda (July-December 2015). The collection of different sets 
of material from different physical and virtual sites - all discussing Finnish-Swedish border security and the Tornio border crossing in 2015-2016 - allows access to many different versions of border securitization and embedded power relations. The media reports and social media discussions illustrate attitudes of a different kind with respect to the border compared to the face-to-face interviews with people who participated in border surveillance and asylum reception on the ground. The state intervention at the Finnish-Swedish border was a temporal phenomenon and it was not possible to start ethnographical research immediately (research permission and resources were not available in time), something that precluded direct participant observation of the reception as a lived practice.

The different sets of documented material, media reports, social media and interviews, provide us with insight into the extant meanings of border and into the practices of security/insecurity that were conducted by state and non-state actors. The interviews and the questionnaire also provide knowledge of how the mobilization of anti-immigration groups and nationalistic "close the border" demonstrations were experienced and seen by the borderland people. The interviews and the other materials are evaluated contextually to appraise how societal power relations, possible contestations of state territorial sovereignty with respect to securitization, for example, are manifest in different practices and discourses. The border securitization multiple approach therefore needs to be seen simultaneously as an analysis of power nexuses, how these materialize in and through border securitization, and in the legitimation of particular representations of the world (Foucault 1972; Müller 2008). The different sets of material provide access to different, and differential, sites of authorization in which border securitization is enacted, discussed and claimed. In the following sections, the research material and findings are organized and interpreted in order to discuss the securitization of the Finnish-Swedish border as multiple and how the possible different versions of territorial sovereignty are played out. 


\section{Securitization and state intervention in Tornio}

The Finnish-Swedish border has been open since World War II and the borderlanders often refer to it as the most peaceful border in the world. The western border has represented a safe passage whereas the eastern Finnish-Russian border has traditionally been viewed as a threat (Harle and Moisio 2000). The town of Tornio (22 000 inhabitants) is located on the Finnish-Swedish border, adjacent to the Swedish town of Haparanda. Tornio and Haparanda are sometimes referred to as twin towns and they have had close institutional cooperation since the 1960s. The openness and predictability of crossborder relations has enabled the border towns to develop an open border brand and to boost the economic develop of this the northern border area through cross-border cooperation. The towns have constructed a common border area and, in 2013, an international bus station built along the border. The station, located right next to the border on the Haparanda side, serves as a hub for both Finnish and Swedish coach transportation. In 2015, this common bus station formed the key node of the migration route from Sweden to Finland and was the place where the Finnish church first received the migrants. The physical yet invisible borderline between Finland and Sweden marked a legalauthoritative space in relation to which the activities and responsibilities were organized. Whereas the state authorities' power and activities were territorially limited, nongovernmental actors were able to provide assistance on both sides of the border.

In mid-September in 2015, the Finnish state started systematic border surveillance at the Tornio border crossing point and relocated hundreds of security authorities and servicemen there. Unlike some other EU countries (COM 2016), Finland did not choose to temporary reintroduce systematic Schengen border control (Schengen Borders Code, article 29), but embraced the idea of focused border checks. Yet, the sudden presence of state authorities and security officials in Tornio changed the border landscape and the meanings associated with it. The interviews pointed out that before state intervention and systematic border surveillance, many locals had experienced the uncontrolled border 
crossing of thousands of migrants as a threat. The influx was described as "sudden," "unpredictable" and even "chaotic." Most people in Tornio supported the border checks even if they themselves had been stopped at the border too, often for the first time in their lives. The security intervention highlighted the borderline as the site where territorial sovereignty is enacted and experienced in different ways

The flow of immigrants that started approximately a year ago in the autumn, it was quite frightening . . . the new people are from the Border Guard organization and Police. The number of officials, it was a huge number that were here. And they were guarding the border all night and day. So of course it will increase security, when you know that your own men are watching who is coming. When you drove over (the border), they spotlighted you from behind with an electric lamp to see if someone was there. (Participant 16, civil society)

The Finnish state and security authorities were not the only actors taking responsibility for migration reception; Finnish volunteers and nongovernmental organizations, especially the Finnish Red Cross, had an important role in the process as well. Finnish nongovernmental actors were able to take activities on the Swedish side, e.g. in the bus station, with the Swedish police providing support. Besides the well-established organizations, many ad hoc pro-immigration groups were mobilized in social media forums to provide help, distributing donations, clothing and beverages, and privately accommodating some asylum-seekers. The success of this cooperation and the experience of mutual trust was emphasized in the interviews. The local authorities and nongovernmental actors did not often speak of experiences of insecurity but of smooth cooperation and practicalities, feelings of trust and safety. The formation of trust relationships and responsibilities between the state authorities and nongovernmental organizations has a historical background. In Finland, the development of civil society has traditionally occurred in a 'top-down' manner, emphasizing the republican values of equality and fraternity (Häkli 2005). 
The interviews pointed out that alongside the domestic cooperation and partnerships, the mobilization of transnational cooperation and networks formed an important foundation for the effective organizing of the migrant reception. The presence of the Swedish police in the area of the bus station also created the feeling of security for those Finnish volunteers and nongovernmental actors who guided the migrants from the Swedish side to the Finnish side across the border. Some of the interviewed people highlighted that carrying even a migrant child across the border would constitute human trafficking; everyone had to cross the border with their own feet. According to the interviewed officials, interagency cooperation played a crucial role in the organization of asylum reception. The informants described that each authority and organization had its own network and contact persons in Sweden, which provided information about the volumes and estimated times of new arrivals. Timely information about the movements and routes of migrants in Sweden was considered crucial for planning the reception in Tornio.

The border securitization activities and cooperation among and between governmental and nongovernmental actors in Finland and across the Finnish-Swedish border support the notion of hybrid sovereignty that is enacted by state-non-state entities (Fregonese 2012a). Although the power and capacities of the state and non-state actors were differently constituted in relation to the borderline and state territory, from the perspective of sovereignty their securitization activities were parallel. By this means, border securitization activities regenerated the state-civil society nexus in Finland. The Lutheran Church, however, has questioned the state authority in deciding about human protection by hiding some migrants who are ordered to be deported.

\section{Municipality autonomy and state power}

Collaboration, networking and information sharing among governmental and non-governmental actors characterized the interview stories of the local maintenance and reception of asylum-seekers at the Finnish-Swedish border crossing point of Tornio. The media reports and interviews with 
municipal actors showed, however, that the capacity of the reception became a critical issue in Finland, and organizing asylum reception provoked interstate conflicts. At the height of the migration, one new asylum reception unit was being established every day in Finland and the busses transporting the asylum-seekers were informed of their destination as they drove south. The volume of the process of the asylum-seeker reception is illustrated by the numbers: from January 2014 to January 2015 the number of reception units in Finland increased from 20 to 144, and the number of units for unaccompanied minor asylum-seekers from 8 to 68 (EMN 2016, 22).

Tornio, like many other Finnish municipalities, was skeptical towards the state's proposal to establish reception centers in the district. Some municipalities refused to offer accommodation facilities in their districts; however, the Finnish Immigration Service then turned to private housing solutions. This provoked a debate about the authority of municipalities in their administrative districts (The Union of Municipalities 2016). The state authorities responsible for the asylum reception underlined that volunteerism and agreements were the first measure but not the only one, and that Finland was responsible for the placement of the arrivals:

When the numbers (of asylum-seekers) are this high and more people come every day, at some point we may be in a situation where we cannot find enough of these centers and we have to use the powers that we possess. Although I hope that we don't have to go to that. (Ministry of the Interior, Petteri Orpo 2015)

The interviews pointed out that the state intervention at the Tornio border crossing point was considered exceptional yet rather necessary by the local authorities who collaborated on practical issues with the national migration and security authorities. Registration was the first step of the asylum process and it was seen as important that it would be conducted in a controlled manner in Tornio, where the migrants first entered Finnish territory. Although the surveillance of the FinnishSwedish border was seen in a positive light, the establishment of the registration center in Tornio was 
initially opposed by several town councilmembers. That the state threatened to bypass municipality autonomy was a surprise to the local authorities:

I realized that, of course, if the state sees that, in the name of national interest, the former secondary school of Tornio will be turned into a registration center, it will be done without the permission of the town councilmembers. However, luckily they understood that it was not really a question of debate but a hint that even if you do not cooperate, it will be taken anyway. It showed that the border exists, and the state intervene as it wishes. (Participant 1, municipality authority)

Even though the state was the main authority of border securitization, operating through a multitude of institutional practices and in cooperation with nongovernmental actors, the extent to which state ministries maintain the legitimate authority to make decisions over the heads of local municipality representatives became an issue. In Finland, municipalities have strong autonomy and the organization of asylum maintenance created tensions between state authority and municipality autonomy. The need to shelter and maintain the asylum-seekers pushed the ministries and stakeholders to threaten the municipalities with the right to overrule them, to decide the exception (Doty 2007; Schmitt 1997/1922). The state intervention and securitization of the Tornio border crossing both reifies and problematizes the concept of territorial sovereignty, not just in terms of the restrictions that were placed on the movement of migrants and citizens, but also in terms of the difficulties that arise around taking exceptional decisions in the administrative area of a municipality while simultaneously being fully dependent on the willingness of the municipality to cooperate. This suggests that hybridized sovereignty is interlinked with persuasive governance more than on coercive methods (Foucault 2004; Miller and Rose 2008). However, the state and municipality actor versions of border securitization in relation to territorial sovereignty contain shared but also different concerns. 


\section{Extreme nationalism and the contested authority of securitization}

While the municipality authorities in Tornio were, in the end, willing to cooperate with the ministries and the Finnish Migration Service, some civilian extreme nationalist groups started to contest the state's efficiency and methods for border securitization from below. The border town of Tornio became a site for heated debates, and demonstrations for and against migration were organized near the border crossing point. Anti-immigrant groups loudly opposed the increasing number of migrants and asylum-seekers, something that created social mistrust and a specific aggressive "affective atmosphere of nationalism" (cf. Stephens 2016). Racist and stigmatizing stories and metaphors, such as "Islamic invasion," "strangers" and "beard children" were circulated in the social media, where asylum-seekers were pictured as a threat to European values, Finnishness, and the economic and cultural resilience of the state (Suomi24 TornioHaaparanta 2015). The anti-immigration rhetoric and the mobilization of vigilantes did not appear out of thin air; instead, the phenomenon can be interpreted against the long history of nationalism, austerity politics and the wider political turbulence that resulted from the 2015 election in which the nationalistic True Finns Party was, for the first time ever, included in a coalition government alongside the Centre Party and the National Coalition Party. The government started its work in a difficult economic situation, adapting to austerity policies and increasing unemployment. Research has pointed out that the 2015 border securitization issue and the rise of extreme nationalism had a negative impact on Finnish society as a whole, and many people were afraid to speak openly about their attitudes towards migration (Puustinen et al. 2017).

The establishment of new infrastructures of asylum reception resulted in opposition and even acts of violence towards the reception centers and towards immigration officials, civil servants and volunteers. A particular extreme-nationalist group called Soldiers of Odin started street patrols in the Kemi-Tornio region and in several other Finnish towns. The right-wing group's autonomic, ethnically 
targeted securitization from below was soon seen as a security threat from the perspective of state internal security. In the interviews, several nongovernmental female workers reported friction:

It was a threat, in a way. It was not so much a threat to us volunteers who worked there.

There were local people who came to watch us, the people who were against the reception, but their behavior was mostly correct. And all the time the Swedish police was guarding there, so that there were not any riots or anything like that. But they were watching us. (Participant 9, civil society)

The social media discussion forums played a significant role in mobilizing nationalistic "close the border" demonstrations but also pro-immigration counter protests in the towns of Tornio and Haparanda. The forums were utilized to organize demonstrations in Tornio in which hundreds of people from across Finland travelled to participate. The everyday geopolitics of social media discussion became a highly ambivalent, contested and emotionally laden issue. The circulation of images and emotions of danger was embellished with narratives of historical geopolitical relations and cultural othering. In the social media debate, the distinction between the inside and the outside was produced through the circulation of emotions (cf. Stephens 2016, 184; Ahmed 2004). The heated debate - which is best described in terms of national identity securitization and fear of losing hegemonic cultural identity - created opposition between nations, citizens, and migrants, and extended throughout Finnish society in rather ambivalent ways. Hate speech and even physical attacks were directed against reception centers, politicians, and those nongovernmental actors who participated in asylum maintenance, as well as workers and volunteers from the Finnish Red Cross and the Lutheran Church, in particular.

The "close the borders" provocations and heightened nationalism were considered awkward by many, or even a national disgrace. Arguments for and against migration, street patrolling and demonstrations were put forward in the TornioHaparanda Suomi24 social media forum: 
How is my or anyone else's security increased by some fanatic one-truth rioters in our city? In this country, it is totally different powers that are be responsible for security. (TornioHaparanda Social media 2015/10)

The negligence and passivity of authorities in matters of citizen safety will raise the popularity of the so-called extremist movements. This is not necessarily a bad thing when seen from the perspective of the security of Finns in their own country and in the long term (Survey, Tornio 135).

In the survey, some respondents saw that the demonstrations had a positive impact because they forced the state to take a more active role in the border area. However, in the face-to-face interviews most informants had a negative attitude towards the demonstrations. The anti-immigration protests were seen as something that was organized by outsiders, not something that described the local people and their mentality. The nationalist demonstrations were often portrayed in a more negative light than the unauthorized migrants were. The demonstrations were described as troublesome, as something that interrupted others' work and the we spirit of the borderland people:

They come from Tampere, or wherever they were drummed up. They were not from Tornio. It was irritating that these brawlers came to our peaceful border. After that, this has not been called the most peaceful border in the world. They destroyed the brand that had been built for years, that we have a border that is not a border. Then comes this group who wants to close the border. For me it was a terrible thing. (Participant 8, civil society).

From the perspective of state sovereignty, the contestation of the effectiveness of the practices of border securitization by the vigilantes is a complex question. Doty $(2007,116)$, who has studied the civilian border patrols of the U.S. borderlands, argues that such border vigilantism problematizes the prevailing understanding of the state as constituting the only site of the sovereign, or more precisely, 
the sovereign's decision on the exception. This points out how border securitization is not something that is initiated solely in the name of state authority and by following the state code of conduct. The multiple sites and contradictory practices of securitization clearly point out that the work of sovereignty cannot be understood merely in terms of central state authority, as a condition in which "an agent of a state can make commands that are voluntarily complied with by those over whom the state claims authority" (Agnew 2005, 399). From the perspective of the border securitization multiple approach, the nationalistic securitization from below can be understood to provide an alternative version of territorial sovereignty, what sovereignty should mean and how it should be played out.

\section{Neighborly relations and solidarity}

The 2015 migration influx challenged the geopolitical meanings of the Finnish borders in many ways. Finland has not normally been a destination country, and it was difficult for many to realize that migrants wanted to continue to Finland from Sweden, which is usually considered a more attractive destination. The situation at the Tornio border crossing point was constantly reported on in national broadcasts and the state intervention at the border gained international visibility. The Nordic countries have shared their sovereignty in the domain of border management for decades; the countries have had common 'external' borders since a 1957 agreement on the removal of visa requirements between the countries. Moreover, Finland and Sweden have been EU member states since 1995 and part of the Schengen area since 2001, and thus have voluntarily ceded a remarkable degree of sovereignty and abolished regular border control between themselves. Agnew $(2005,441-2)$ terms this voluntary sharing of sovereignty, motivated by an increased capacity for responding to economic and social turbulence in the mobile world as well as environmental problems, as "disaggregated sovereignty." Finland and Sweden therefore can be seen to have a double agreement on unrestricted border crossing. It is thus not surprising that he intensified border controls and militarization of the Tornio border crossing point was criticized in Sweden, in particular. Many interviewed people told that they were 
surprised how strong the reaction from the Swedish side was at first and that border securitization impacted their everyday relations in the borderland:

When the military servicemen came here [to the border] and then the Border Guard service, with guns, the soldiers . . they contacted us immediately from Sweden and wanted to know what was going on. (Participant 3, state authority)

Most of my colleagues are Swedes. They were very angry at Finns when the border controls were established. They though that Finland cannot do that. This is against the rules and agreements. They were angry, saying that they certainly will not show their identity card if asked at the border. But it did not last very long and now Sweden does that there too [later in 2015 Sweden started the temporary reimplementation of border controls on the Swedish-Danish border] (Participant 16, civil society)

The narrative of a good neighbors was contested and some Finnish people even argued that Russia had now become a more reliable neighbor than Sweden. This debate marked a significant change in the discourse of Finnish borders. For the Finns, geopolitical threat is usually associated with the Finnish-Russian border whereas the Finnish-Swedish border has long represented a safe passage and a cultural link with the western world (Harle and Moisio 2000).

Historical narratives of borders and migration were put to work in the media and politicians in both Finland and Sweden sued them to justify their stances for or against border controls. Finnish authorities accused Sweden of not abiding by the Dublin Agreement and the Swedish Foreign Minister Margot Wallström and the Minister of Interior Anders Ygeman reminded Finland that Sweden took in more than 70000 Finnish war evacuees during the Second World War, underlining that this creates a certain kind of historical responsibility to help refugees.

I would like to note that it was not a long time ago that Finns had to flee because there was a war. I believe very few people saw that it was wrong for Sweden and others to 
take in refugees. (Anders Ygeman, the Minister of Interior in Sweden, in Helsingin Sanomat 2015)

Politicization of historical events and the statements of the Swedish media and ministers attracted much attention and such arguments were used to oppose or support asylum reception. It was noted for example that only Finnish children were evacuated to Sweden, and that Finland had protected Sweden by fighting the Soviet Union. The good neighboring relations between Finland and Sweden were seen to be under threat. The tension between Finland and Sweden is illustrative of a larger EU solidarity crisis about conflicting interests and uneven distribution of responsibilities in the asylum reception. As Brown remarks, in 2015, the solidarity and agreements between the EU countries was tested, and the force of the Dublin regulation (EU 604/2013), an agreement stipulating that the migrant's country of entry into the EU is the country responsible for handling his or her asylum claim, was emptied. The migrants' routes through Europe were transformed into organized channels that facilitated the movement of peoples to reach the new destination countries, thus changing also the established notions of "transit" and "destination" countries (Brown 2017).

\section{Discussion}

The literature of EU internal border areas has reported on border opening and successful cross-border cooperation. However, during the last decade the discourse on European borders and border regions has changed significantly. Many EU countries have temporality reintroduced the security border and conducted systematic border controls to block the movement of migrants from neighboring EU countries. Even the Nordic countries, where people have enjoyed free movement for decades, have reintroduced border controls and the authorities are trying to integrate the reinforced security approach. The tightening of border control can be interpreted as a shift from the EU neoliberal free market logic towards a nationally determined border securitization framework. 
As this study of border securitization shows, border security interventions may create new forms of connectivity among security authorities, state and civil society, and may empower extreme nationalistic movements, simultaneously severely disrupting other forms of international mobility, collaboration and societal trust relations. From the perspective of the Finnish state, the securitization of the Finnish-Swedish border can be interpreted as an attempt to bring mobile migrants within the 'gaze' of state authorities and institutions (cf. Vigneswaran 2013). The movements of migrants are channeled and they are made governable by registration right at the border, being categorized on the basis of their political, ethnic, religious and family status. Yet, as this study point out, border securitization is formed in a complicated arena of parallel but also ambiguous activities conducted by both governmental and nongovernmental actors in and through which different versions of territorial sovereignty are simultaneously co-constituted and contested by wider transnational relations of solidarity as well as by the local securitization efforts of vigilantes. The securitization of the FinnishSwedish border, and its effects, is not the same for all actors and groups of actors. This study therefore confirms the criticism directed at the theory of securitization for its tendency to assume a clear division between state and society, and the theory the states are entities that maintain a coherent identity (Doty 2007, 19).

Border securitization is not a value-free or culturally empty domain of activity but becomes entangled with the long-lasting geopolitical and cultural imaginations of threat and danger (van Houtum and Pijpers 2007). In Finland, border securitization forms an integral part of national identity construction and has a prominent role in making geopolitical divisions between friends and enemies (cf. Campbell 1992; Bialasiewicz et al. 2007). National protectionism and identity securitization still form the driving forces behind border policy, that is, despite the fact that EU membership has to some extent changed the ways that border authorities conceptualize border security - not just as a matter of state territorial sovereignty but as a cooperative effort - in the minds of ordinary people the actual physical border is the location where the protection of the state and society takes place (Prokkola 2013b). 
Nevertheless, the influx of migrants and asylum-seekers across the northern Finnish-Swedish border crossing point at least temporality changed the geopolitical imaginaries of the Finnish borders, in which threats are normally seen to come from the east, and definitely not from the west. The practices and discourses of border securitization need to be interpreted against the geopolitical and contextual factors that they may also challenge; for example, the 2015 securitization of Finnish-Swedish border crossing was seen to call into question the prevailing geopolitical east-west friend-enemy axis.

Research shows that threat discourses have a negative effect on unauthorized migrants, on those migrants and ethnic minorities who hold a legal status and a residence permit (van Baar 2017), and on societies as a whole. The border securitization multiple approach highlights how securitization is not a one-way state-driven process, but is enacted by various actors and interest groups for whom security may mean different things. The state's capacity in establishing the code of conduct on border securitization is depended on cooperation, trust and information sharing with various groups of actors. Finland and Sweden have a long historical relationship, yet today the securitization of the FinnishSwedish border cannot be interpreted separately from EU integrated border management (IBM) and the Schengen Agreement. These agreements mean that the member states voluntarily share their territorial sovereignty, giving up some of their legal-authoritative rights to make independent decisions about border enforcement. As Longo (2018) explains, the so-called sovereign states are increasingly relying on non-sovereign means of co-bordering, that is, collaboration, sharing and trust. In the Schengen area and North America, border officers are increasingly reliant on databases stemming from non-national sources, the decisions of entry rely on data and algorithms that are not completely controlled by the state. The decision of entry is in a way "stripped of sovereign exclusivity" (Longo 2018, 191), however, this version of border securitization and border surveillance methods is still very much hidden from the public consciousness. 
Border securitization is a complex and multifocal process in which prevailing societal orders and power relations are reified, shifted or contested in a way that often heightens social polarization and vulnerability. Border securitization is a field where different versions of territorial sovereignty are argued for, and the state-migrant relationship is continuously renegotiated and often contested by forces from within and beyond state territorial borders. More than the waning of state power (Brown 2010), border securitization efforts illustrate sovereignty as a hybrid constellation, how territorial control and its legitimization is not simply executed in some exclusive realm of sovereign authority. Hybrid sovereignty, however, does not mean that there is only one version of territorial sovereignty, or the significance of borders, but different versions co-exist and some are more dominant than others are.

\section{References}

Ackleson, J. 2005. Constructing Security on the US-Mexico Border. Political Geography 24(2): 165184. doi.org/10.1016/j.polgeo.2004.09.017

Agnew, J. 2005. Sovereignty Regimes: Territoriality and State Authority in Contemporary World Politics. Annals of the Association of American Geographers 95 (2): 437-461. doi: 10.1111/j.1467-8306.2005.00468.x

Ahmed, S. 2004. Collective Feelings. Or, the Impressions Left by Others. Theory, Culture and Society 21 (2): 25-42. doi.org/10.1177/0263276404042133

Andersen, D., and M. Sandberg. 2012. Introduction. In The Border Multiple: The Practicing of Borders Between Public Policy and Everyday Life in a RE-scaling Europe, eds. Andersen, D., M. Klatt, and M. Sandberg, 1-23. Farnham: Ashgate. 
Andersen, D. O. Kramsch and M. Sandberg. 2015. Inverting the Telescope on Borders that Matter: Conversations in Café Europe. Journal of Contemporary European Studies 23 (4): 459-476. doi.org/10.1080/14782804.2015.1068164

van Baar, H. 2017. Evictability and the Biopolitical Bordering of Europe. Antipode 49 (1): 212-230. DOI: 10.1111/anti.12260

Balzacq, T. 2005. The three faces of securitization: Political agency, audience and context. European Journal of International Relations 11: 2, 171-201.

Bialasiewicz, L., D. Campbell, S. Elden, S. Graham, A. Jeffrey and A. Williams. 2007. Performing security: The imaginative geographies of current US strategy. Political Geography 26(4): 405422.

Bigo, D. 2001. The Möbius Ribbon of Internal and External Security(ies). In Identities, Borders, Orders: Rethinking International Relations Theory, ed A. Mathias, 91-117. Minneapolis, NM: University of Minnesota Press.

Brown, W. 2010. Walled states, waning sovereignty. Cambridge: MIT Press.

Brown, W. 2017. Border barriers as sovereign swords: rethinking Walled States in light of the EU migrant and fiscal crises. In Interventions on the state of sovereignty at the border, ed. R. Jones, C. Johnson, W. Brown, G. Popescu, P. Pallister-Wilkins, A. Mountz and E. Gilbert, 1-10. Political Geography 59.

Buzan, B., O, Wæver, and J. de Wilde. 1998. Security: A New Framework for Analysis. London: Lynne Rienner Publichers.

Campbell, D. 1992. Writing security: United States Foreign Policy and the Politics of Identity. Minneapolis: University of Minnesota Press.

Casas-Cortes, M., S. Cobarrubias and J. Pickles. 2016. 'Good neighbours make good fences': Seahorse operations, border externalization and extra-territoriality. European Urban and Regional Studies 23 (3): 231-251. doi.org/10.1177/0969776414541136 
Coleman, M. 2009. What Counts as the Politics and Practice of Security, and Where? Devolution and Immigrant Insecurity after 9/11. Annals of the Association of American Geographers 99 (5): 904-913. DOI.org/10.1080/00045600903245888

COM. 2016. Temporary Reintroduction of Border Control. European Commissions Migration and Home Affairs. Available at >https://ec.europa.eu/home-affairs/what-we-do/policies/bordersand-visas/schengen/reintroduction-border-control_en $<\left(\right.$ Accessed $25^{\text {th }}$ October 2017)

Doty, R. 2007. States of Exception on the Mexico-U.S. Border: Security, “Decisions,” and Civilian Border Patrols. International Political Sociology 1 (2): 113-137. DOI: 10.1111/j.17495687.2007.00008.x

EC. 2018. Notifications of the Temporary Reintroduction of Border Control. European Commission: Migration and Home Affairs. Available at >https://ec.europa.eu/homeaffairs/sites/homeaffairs/files/what-we-do/policies/borders-and-visas/schengen/reintroductionborder-control/docs/ms_notifications___reintroduction_of_border_control_en.pdf< (Accesses 7 August 2018)

EMN. 2016. European Migration Network. Key figures on immigration 2015. Published by European Migration Network \& Finnish Immigration Service, Finland. Available at >http://www.emn.fi/files/1361/EMN_maahanmuuton_tunnusl_2015_EN_tumma.pdf< (Accessed 25 October 2017)

Foucault, M. 1972. The Archaeology of Knowledge and The Discourse on Language. New York: Patheon Books.

Foucault, M. (1991) Governmentality. In G. Burchell, C. Gordon \& P. Miller (Eds.), The Foucault effect: Studies in governmentality, pp. 119-50. Chicago: University of Chicago Press.

FRC. 2017. Finnish Refugee Council. Pakolaisuus Suomessa. Available at >http://pakolaisapu.fi/pakolaisuus/pakolaisuus-suomessa/< (Accessed 24 October 2017) 
Fregonese, S. 2012a. Urban Geopolitics 8 Years on. Hybrid Sovereignties, the Everyday, and Geographies of Peace. Geography Compass 6 (5): 290-303. doi10.1111/j.17498198.2012.00485.x

Fregonese, S. 2012b. Beyond the 'Weak State': Hybrid Sovereignties in Beirut. Environment and Planning D: Society and Space 30 (4): 655-674. doi.org/10.1068/d11410

Harle, V. and S. Moisio. 2000. Missä on Suomi?: kansallisen identiteettipolitiikan historia ja geopolitiikka. Tampere: Vastapaino.

van Houtum, H., and R. Pijpers. 2007. The European Union as a Gated Community: The Two-faced Border and Immigration Regime of the EU. Antipode 39 (2): 291-309. DOI: 10.1111/j.14678330.2007.00522.x

Hyndman, J. 2010. The Geopolitics of Migration and Mobility. Geopolitics 17 (2), 243-255. doi.org/10.1080/14650045.2011.569321

Huysmans, J. 2000. The European Union and the Securitization of Migration. Journal of Common Market Studies 38 (5): 751-777. DOI: 10.1111/1468-5965.00263

Häkli, J. 2005. Who is the Finn?: Globalization and Identity in Finland. Journal of Finnish Studies 9 (2): 12-26.

Jones, R. 2012. Border walls: Security and the war on terror in the United States, India, and Israel. London: Zed Books.

Jones, R., and C. Johnson. 2017. Corridors, camps, and spaces of confinement. In Interventions on the state of sovereignty at the border, ed. R. Jones, C. Johnson, W. Brown, G. Popescu, P. Pallister-Wilkins, A. Mountz and E. Gilbert, 1-10. Political Geography 59.

Kuus, M., and J. Agnew. 2008. Theorizing the state geographically: sovereignty, subjectivity, territoriality. The Sage Handbook of Political Geography, eds. K. Cox, M. Low, and J. Robinson, 95-106. London: Sage. 
Longo, M. 2018. The Politics of Borders: Sovereignty, Security, and the Citizen after 9/11, Cambridge: Cambridge University Press,

Miller, P. \& N. Rose (2008). Governing the Present. Administering Economic, Social and Personal Life. Cambridge: Polity Press.

Mol, A. 1999. Ontological politics. A word and some questions. The Sociological Review 47 (1): $74-$ 89. doi.org/10.1111/j.1467-954X.1999.tb03483.x

Mol, A. 2002. The body multiple: ontology in medical practice. Durham: Duke University Press.

Mountz, A. 2013. Reconfiguring geographies of sovereignty. Progress in Human Geography 37 (6): 829-841. doi.org/10.1177/0309132513479076

Mountz, A., and N. Hiemstra (2014). Chaos and Crisis: Dissecting the Spatiotemporal Logics of Contemporary Migrations and State Practices. Annals of the Association of American Geographers 104 (2), 382-390. doi.org/10.1080/00045608.2013.857547

Müller, M. 2008. Reconsidering the concept of discourse for the field of critical geopolitics: Towards discourse as language and practice. Political Geography 28: 330. doi.org/10.1016/j.polgeo.2007.12.003

Paasi, A. 2016. Dancing on the graves: Independence, hot/banal nationalism and the mobilization of memory. Political Geography 54: 21-31. doi.org/10.1016/j.polgeo.2015.07.005

Pascucci, E., Kallio, K. P. and Häkli, J. (2019). "Delay and neglect”: the everyday geopolitics of humanitarian borders. In Borderless Worlds for Whom? Ethics, Moralities and Mobilities, ed. A. Paasi, E-K. Prokkola, J. Saarinen and K. Zimmerbauer. London: Routledge.

Philpott, D. 1995. Sovereignty: An Introduction and Brief History. Journal of International Affairs 48 (2): 353-368.

Prokkola, E-K. 2013a. Neoliberalizing Border Management in Finland and in Schengen. Antipode 45 (5): 1318-1336. 
Prokkola, E-K. 2013b. Technologies of Border Management: Performances and Calculation of Finnish/Schengen $\quad$ Border $\quad$ Security. Geopolitics $13 \quad$ (1): 77-94. doi.org/10.1080/14650045.2012.685791

Prokkola, E-K. 2019. Asylum reception and the politicization of national identity in Finland: a gender perspective. In Borderless Worlds for Whom? Ethics, Moralities and Mobilities, ed. A. Paasi, E-K. Prokkola, J. Saarinen and K. Zimmerbauer. London: Routledge.

Puustinen, A., H. Raisio, E. Kokki, and J. Luhta. 2017. Kansalaismielipide: Turvapaikanhakijat ja turvapaikkapolitiikka. Sisäministeriön julkaisu 9/2017. Available at :>http://julkaisut.valtioneuvosto.fi/bitstream/handle/10024/79477/09_2017_Kansalaismielipid e\%20Turvapaikanhakijat\%20ja\%20turvapaikkapolitiikka.pdf< (accesses 25 October 2017)

Rumford, C. 2008. Citizens and Borderwork in Europe. Space and Polity 12 (1): 1-12. doi.org/10.1080/13562570801969333

Schmitt, C. 1997/1922. Poliittinen teologia/ Politische Theologie. Tutkijaliiton julkaisu 86. Hamina: Kotkan kirjapaino Oy.

Sharp, J. 1996. Hegemony, popular culture and geopolitics: the Reader's Digest and the construction of danger. Political Geography 15 (6-7): 557-570. doi.org/10.1016/0962-6298(96)00031-5

Stephens, A. 2015. The affective atmospheres of nationalism. Cultural Geographies 23 (2): 181-198. doi.org/10.1177/1474474015569994

Stritzel, H. 2007. Towards a Theory of Securitization: Copenhagen and Beyond. European Journal of International Relations 13 (3): 357-383. doi.org/10.1177/1354066107080128

Tesfahuney, M. 1998. Mobility, racism and geopolitics. Political Geography 17 (5): 499-515 499515. doi.org/10.1016/S0962-6298(97)00022-X

Vigneswaran, C. 2013. Territory, Migration and the Evolution of the International System. London: Palgrave Macmillan. 